\title{
Male as the Disadvantaged Sex for Childhood Disabilities: Analysis of Data From the National Disability Registry of Taiwan
}

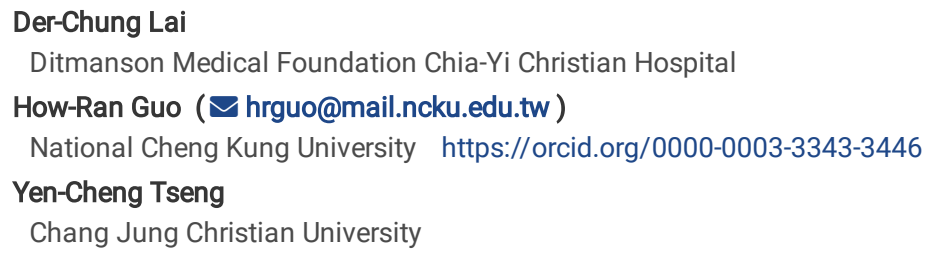

\section{Research}

Keywords: autism spectrum disorders, childhood disability, developmental disability, national disability registry, sex

Posted Date: June 29th, 2021

DOI: https://doi.org/10.21203/rs.3.rs-634630/v1

License: () (i) This work is licensed under a Creative Commons Attribution 4.0 International License. Read Full License 


\section{Abstract}

Background: Many studies have examined sex differences in specific types of childhood disability, but data on the full range of disability are limited. Such data allow comparisons among disabilities and are valuable to the inference of etiology. To provide benefits and services, the Taiwanese government certifies disabled citizens and maintains a registry. We used the registry to evaluate sex differences in childhood disability and assess changes over time.

Methods: We analyses the registry data from 2000 to 2011 and included all children who were at least 3 years of age, because certification before 3 years of age was discouraged by the government. We calculated the male-to-female rate ratios (RRs) for all disabilities combined and nine major disability categories, namely autism spectrum disorders (ASD), hearing impairment (HI), intellectual disability (ID), loss of function of major organs (LFMO), motor disability (MD), multiple disabilities, speech and language disability (SLD), visual impairment (VI), and other disabilities. In addition, we assessed the changes in the RRs over time.

Results: The total number of cases between 3 to 17 years of age registered each year ranged between 49242 and 61717 . Males generally had higher prevalence than females, and disabilities due to primarily neurodevelopmental conditions (ASD, ID, and SLD) had higher male-to-female RRs than disabilities due to primarily physical conditions (HI, LFMO, MD, and VI). The RRs of all disabilities combined increased over time, but the sex differences in ID, MD, and "other disabilities" decreased over time, while those in ASD, SLD, and multiple disabilities increased. The RRs of all disabilities combined decreased with age in most years, but the trends were different across individual disabilities.

Conclusions: Male is the disadvantaged sex for childhood disabilities. The sex differences in disabilities due to primarily neurodevelopmental conditions were more prominent than those in disabilities due to primarily physical conditions. With the decreasing number of children given birth and growing awareness of sexual disparity during the study period in Taiwan, the RRs had an increasing time trend, instead of decreasing, which suggested that genetic causes have larger contributions to the sex differences in childhood disability than environmental causes.

\section{Introduction}

Sex difference is an important issue of health in children. ${ }^{1,2}$ Studying the variability of the prevalence of childhood disabilities by sex characteristics may generate insight into developmental disabilities and provide clues for further etiological research. ${ }^{3,4}$ A study used the data of 1987 Finnish Medical Birth Register and followed up children's health until the age of 7 years found that boys in childhood had more health-related problems than girls. ${ }^{1}$ The difference might also be true for childhood disability. Previous studies had recognised male predominance in certain childhood disabilities. For example, a review of literature on autism spectrum disorder (ASD) showed that the reported male-to-female ratios ranged from 1.33:1 to 15.7:1, with a mean of 4.2:1. ${ }^{5}$ Many studies on intellectual disability (ID) found higher prevalence rates in boys than in girls ${ }^{6-7}$ and reported male-to-female ratios around $1.5: 1 .^{8}$ Male predominance has also been found in childhood deafness, and a study reported a male-to-female ratio of 1.17:1. ${ }^{9}$

Few studies, however, have provided a full picture of the sex difference in childhood disabilities. Such data allow comparisons among disabilities and thus are valuable to the inference of etiology. The National Health Interview Surveys (NHIS) in the U.S.A. examined the prevalence of 10 categories of developmental disabilities (attention deficit hyperactivity disorder, autism, blind, cerebral palsy, moderate to profound hearing loss, learning disabilities, intellectual disabilities, seizures, stuttered, and other developmental delays) in children aged 3 to 17 years and found that boys generally had higher prevalence rates than girls, except for cerebral palsy $(0.36 \%$ vs. $0.37 \%) .{ }^{10}$ A national survey of the non-institutionalized population in China also found that the prevalence of six categories of disabilities (hearing, intellectual, mental, physical, speech, and visual) were all higher in boys than in girls in children under 20 year-old. ${ }^{11-13}$

In Taiwan, according to the Disabled Welfare Act, ${ }^{14}$ the local governments certify qualified disabled residents to provided various services and benefits, and the central government maintains a registry of certified cases. ${ }^{15}$ Data from the registry present a rare opportunity for studying the sex difference on the full range of childhood disabilities at the national level. With the data, the time trends in the sex difference can be assessed and comparisons among different types of disabilities can be made-both are seldom achieved in previous studies. Therefore, we conducted a study using the national disability registry data from 2000 to 2011 to fill the data gaps.

\section{Methods}

\section{The disability registry system in Taiwan}

The Disabled Welfare Act implemented in 1980 has facilitated the promotion of benefits for the disable in Taiwan. ${ }^{14}$ It mandates the local governments provide services to residents with 16 categories of disabilities, namely "autism spectrum disorders," (ASD) "balance disability," "chronic psychiatric disorders," "dementia," "facial damage," "hearing impairment (HI)," "intellectual disability (ID)," "intractable epilepsy," "loss of function of major organs (LFMO)," "motor disability (MD)," "multiple disabilities," "other disabilities listed by the government (other disabilities), " "rare diseases with physical or mental disabilities listed by the government," "speech and language disability (SLD)" "vegetative state," and "visual impairment (VI)." "Multiple disabilities" refers to cases with two or more disabilities. ${ }^{15}$

Patients with disabilities can make applications for certification through the local government of their residential area, and the local governments report cases to the central government. The central government maintains a national disability registry of certified cases and publishes summary data each year. ${ }^{15}$ The registry have become a valuable source of information for research. ${ }^{16-22}$

\section{Case definition}


When a child is suspected to have a disability that is qualified for the benefits, a parent or guardian can apply for certification through the local government office in the residential area on the child's behalf. To be certified, a patient must fit the criteria listed by the government (Supplement Table I) ${ }^{23}$ and be confirmed by a doctor accredited by the government. ${ }^{24}$

Because the numbers of childhood cases in seven categories (balance disability, chronic psychiatric disorders, dementia, facial damage, intractable epilepsy, rare diseases with physical or mental disabilities listed by the government, and vegetative state) were relatively small in all years, ${ }^{15}$ we combined them into the category "the remaining seven categories of disabilities." This category was included in the overall analyses, but separate analyses were limited to the remaining nine main categories.

\section{Data collection}

On the basis of information collected through the registry, the central government of Taiwan publishes Statistical Yearbook each year. Before the reorganization of the government in 2013, the reports were published by the Ministry of the Interior, and Ministry of Health and Welfare took over the task afterwards. ${ }^{15}$ The reports include the numbers of cases by age and disability category, but not the number of cases by sex in each age group. We obtained such data from the Department of Statistics of Ministry of the Interior, but they were not available until 2000.

Because there was a major revision of the criteria in $2012,{ }^{25}$ we analyzed the data from 2000 to 2011 . We limited our study further to cases who were at least 3 years old because the government generally discourages the certification under 3 years of age. ${ }^{26}$ According to the governmental reports, we categorized age into " $3-5$ years," "6-11 years," "12-14 years," and "15-17 years." To calculate the prevalence rates, we obtained data on the numbers of boys and girls by age group from the Monthly Bulletin of Interior Statistics. ${ }^{27}$

\section{Data analysis}

We estimated the prevalence rate in each sex by dividing the number of cases by the number of individuals in a specific group. To assess the sex differences, we calculated the male-to-female prevalence rate ratio (RR) by dividing the prevalence rate in males by that in females in a given year. We also calculated the 95\% confidence interval $(\mathrm{Cl})$ of each RR. In addition, we evaluated the trends of changes in male-to-female RR for all disabilities combined and each main disability category over time and across age groups.

We classified the nine main disabilities into three categories based on the main features of the disabilities. ${ }^{28}$ ASD, ID, and SLD were classified into "primarily neurodevelopmental or mental health conditions". MD, HI, LFMO, and VI were classified into "primarily physical conditions." Multiple disabilities and "other disabilities" were classified into "unclassifiable conditions."

We presented descriptive statistics of the variables as numbers or prevalence rates and used linear regressions to evaluate the trends of changes in male-tofemale RR over time and across age groups. We conducted all the analyses by using SAS 9.1 and performed tests for time trends at the significance level of 0.05 (two-tailed).

\section{Results}

During the study period, the number of registered patients increased year by year from 49242 in 2000 to the top of 61717 in 2008 and then decreased year by year to 60372 in 2011. The prevalence rates of all disabilities combined and nine main disabilities were constantly higher in boys than in girls (Tables I to III). The male-to-female RRs of all disabilities combined and nine major disabilities generally reached statistical significance in all years $(P<0.05)$, except for $\mathrm{HI}$ in 2010 and 2011 and "other disabilities" in 2008 through 2011 (Tables I to III). Among the nine main disabilities, ASD had the highest mean male-to-female RR (5.88), followed by SLD (1.57), multiple disabilities (1.42), ID (1.37), MD (1.34), VI (1.28), "other disabilities" (1.16), LFMO (1.12), and HI (1.08) (Table III). In general, the disabilities due to primarily neurodevelopmental or mental health conditions (ASD, SLD, and ID) had higher male-to-female RRs than those due to primarily physical conditions (MD, VI, LFMO, and HI).

During the study period, the male-to-female RRs of all disabilities combined generally increased over time (Tables I and II), but the trends were different in individual disabilities (Table III). Specifically, the male-to-female RRs of ASD, SLD, and multiple disabilities had increasing time trends $(P$ for trend $<0.05$ for all three), while those of ID, MD, and "other disabilities" had decreasing time trends ( $P$ for trend $<0.05$ for all three).

The male-to-female RRs of all disabilities combined generally decreased with age in all years ( $P$ for trend $<0.05$ in $2004-2006$ and $2008-2011)$ (Table II), but the trends of male-to-female RRs in nine main disabilities individually were different (Table IV). Using 2011, when the prevalence rates were the highest, for example, we found the male-to-female RRs decreased with age in SLD but increased with age in ASD ( $P$ for trend $<0.05$ for both; Table IV). The time trends in other disabilities did not reach statistical significance, although the decreasing trend in ID $(P$ for trend $=0.07)$ and the increasing trend in VI $(P$ for trend $=0.08)$ were marginally significant.

\section{Discussion}

We found boys constantly had higher prevalence rates than girls, both in the nine major childhood disabilities respectively and in all disabilities combined. This supports the argument that male is the disadvantaged sex for childhood disabilities. In the U.S.A., in addition to the NHIS, ${ }^{10}$ the Metropolitan Atlanta Developmental Disabilities Surveillance Program (MADDSP) also studied multiple disabilities in children simultaneously, including ASD, cerebral palsy, ID, VI, and HI. ${ }^{29,30}$ Among them, ASD, cerebral palsy, ID, and VI were more prevalent in boys, which are compatible with our findings. HI was more prevalent in girls in 1996 (1.2 vs. 1.6 per 1000) but more prevalent in boys in 2000 (1.4 vs. 1.0 per 1000), which compatible with our finding that HI had the smallest sex difference among the five main disabilities studied. 
Many factors have been proposed to contribute to the male predominance of childhood disabilities. In term of biological factors, $\mathrm{X}$-linked conditions such as Fragile $X$ syndrome are less often expressed in females than in males. ${ }^{10}$ In addition, the central nervous system of male infant (and fetus) is more vulnerable to environmental influences such as maternal smoking. ${ }^{6,31}$ Furthermore, females may have a higher threshold for reaching affectation status than males. For example, female patients of ASD carry a greater heritable mutational "genetic load" than male patients. ${ }^{32}$

In terms of social factors, in many cultures, boys generally receive greater attention and thus may have a higher rate of being diagnosed when the symptoms and signs are mild. ${ }^{17}$ In addition, compared to girls, boys are more likely to have behavior problems that may affect others and therefore they are more likely to be referred for services. For example, male patients of ASD show more externalizing behavior problems such as aggressive behavior, hyperactivity, reduced prosocial behavior, and increased repetitive/restricted behaviors and interests, while female patients show more internalizing symptoms such as anxiety and depression. 6,32

We found the disabilities due to primarily neurodevelopmental or mental health conditions had higher male-to-female RRs than those due to primarily physical conditions. ${ }^{28}$ This was also observed in the patients 6 to 21 years old who were served under Individuals with Disabilities Education Act in the U.S.A. between 2015 and $2016 .{ }^{33}$ Specifically, the male-to-female ratio was 5.31:1 for ASD, 2.02:1 for SLD, and 1.39:1 for ID (due to primarily neurodevelopmental or mental health conditions) while it was 1.23:1 for VI, 1.14:1 for $\mathrm{HI}$, and 1.12:1 for deaf-blindness (due to primarily physical conditions). ${ }^{33}$

The etiology of childhood disease could also be largely classified into genetic and environmental causes, ${ }^{34-35}$ and individual childhood disabilities combined different proportions of genetic and environmental causes. The results of the current study suggested that the larger the genetic contribution (heritability), the higher the male predominance. Among the disabilities we studied, ASD had the highest male-to-female RR, and according to the literature, ASD also had the highest heritability. ${ }^{34-35}$ Specifically, many family and twin studies estimated the heritability of ASD to be about 38-90\%, making it the most heritable of all developmental disorders. ${ }^{34-37}$ Studies on ID found that genetic causes were present in $25-50 \%$ of cases, ${ }^{38-40}$ and a review of epidemiology studies on childhood $\mathrm{HI}$ in the U.S.A. found genetic etiology was reported to contribute $7.2-40 \%{ }^{41}$ In our study, among these three conditions, ASD had the highest maleto-female RR, and $\mathrm{HI}$ had the lowest. Therefore, genetic causes seemed to have larger contributions to the sex differences than environmental causes.

We also found that conditions which are more likely to be diagnosed objectively (with more objective signs and quantitative outcomes) tended to have lower male-to-female RRs. For example, during our study period, HI was diagnosed on the basis of on pure tone hearing test results, which are quantitative outcomes with decibel as the unit, ${ }^{19}$ and ASD was diagnosed on the basis of the DSM-IV diagnostic criteria ${ }^{8,16}$ ([1] qualitative impairment in social interaction, [2] qualitative impairments in communication, and [3] restricted repetitive and stereotyped patterns of behavior interests, and activities), which are mainly qualitative outcomes. Specifically, HI (1.08), LFMO (1.12), VI (1.28), and MD (1.34) are more likely to be diagnosed objectively and had the lowest male-tofemale RRs, followed by ID (1.37), while SLD (1.57) and ASD (5.88) relied more on subjective symptoms (qualitative outcomes) for diagnosis and had the highest male-to-female RRs. This was also true in terms of male-to-female ratios among the children who were served under Individuals with Disabilities Education Act in the U.S.A.: 1.12:1 for deaf-blindness, 1.14:1 for HI, and 1.23:1 for VI, followed by 1.39:1 for ID, and then 2.02:1 for SLD and 5.31:1 for ASD. ${ }^{33}$

The fact that boys generally receive more attention, which can lead to a higher diagnostic rate, in traditional Chinese culture is a plausible explanation for the higher prevalence of disabilities in boys. ${ }^{17}$ If so, with the decreasing number of children given birth and growing awareness of sexual disparity during the study period in Taiwan, the male-to-female RRs should have been decreasing. However, we found the RRs of all disabilities combined increased over time, instead of decreased.

We found male-to-female RRs of all disabilities combined, ID, and SLD decreasing with age between 3 and 17 years in most years, which is consistent with a census based study of ID in U.S.A. ${ }^{42,43}$ ID is the leading childhood disability and contributed $38.4 \%$ of cases of all disabilities combined in $2011,{ }^{18}$ and therefore we believe the decreasing trend in male-to-female RRs with age observed in all disabilities combined was mainly due to the contribution of ID. In fact, such a trend was not observed in multiple disabilities (e.g. 16.5\% in 2011), which contributed the second largest number of cases, and an increasing trend was observed in ASD, which contributed the third largest number of cases (e.g. 14.4\% in 2011). Factors affecting the trend in relation to age may vary across the type of disabilities.

A major limitation of the current study is that the government does not release data on individual cases, and so we could not carry out more detailed analyses. This applies not only to analyses of data on individuals, but also to cross-tabulation of aggregated data. Furthermore, we used prevalence data instead of incidence data, which might affect the assessment of sex differences. Strictly speaking, we were targeting at the etiology of the disabilities, and differences in the incidence are more closely related to the etiology than those in the prevalence, which are also affected by survival. ${ }^{44-46}$ Nonetheless, because most cases of the disabilities we studied are not fatal but incurable, the relative risks estimated using prevalence data should be very close to those estimated using incidence data. We adopted the "administrative" data from a national registry which obtains the information on qualified persons who applied for the services and thus does not include persons who have not done so. ${ }^{47}$ Consequently, relative risks estimated using the data might be affected by factors influencing the application. However, because the benefits come with the certification are quite substantial, parents or guardians are unlikely to take different actions simply because of the sex of the children, and so the bias introduced should have been minimized.

Compared to previous studies, the current study has some advantages. We studied nine main childhood disabilities at the same time and made comparisons among them, which makes the inference on etiology more comprehensive. This is evidenced by the findings of the more prominent male vulnerability to disabilities due to primarily neurodevelopmental conditions and disabilities with more genetic contribution. In addition, we used data from the whole country, which are seldom available, and the large number of cases (more than sixty thousand cases in 2011 for example) made it possible to generate stable statistical estimates even after stratification of the population. Nonetheless, all the cases were closely examined and certified by physicians, and therefore the diagnoses are reliable. Furthermore, most previous large-scale or nationwide studies were cross-sectional surveys and collected prevalence data for just one 
year, but we had data over a period of 12 years and thus were able to assess the time trends. Besides, because the number of cases under three years of age was small, the prevalence data on the age group 3-5 years can be regarded as close estimates of incidence.

\section{Conclusions}

Our study showed that male is the disadvantage sex in terms of childhood disabilities. The sex differences in disabilities due to primarily neurodevelopmental conditions were more prominent than those in disabilities due to primarily physical conditions. We also found that the larger the proportion of genetic contribution, the more prominent the male vulnerability, indicating genetic causes have larger contributions to the sex differences than environmental causes. However, further studies with data on individual participants are needed to confirm our findings.

\section{Abbreviations}

ASD

autism spectrum disorders; Cl:confidence interval; Hl:hearing impairment; ID:intellectual disability; LFMO:Ioss of function of major organs; MADDSP:Metropolitan Atlanta Developmental Disabilities Surveillance Program; MD:motor disability; NHIS:National Health Interview Surveys; RR:male-tofemale rate ratios; SLD:speech and language disability; VI:visual impairment.

\section{Declarations}

Ethics approval and consent to participate: The study protocol was reviewed and approved by the Institution Review Board of the Ditmanson Medical Foundation Chia-Yi Christian Hospital (reference: No.105002). Consent to participate was waived because this study used secondary data only.

Consent for publication: Not applicable.

Availability of data and materials: The data used in this study are either published by the Taiwanese government or available from the government upon request and review.

Competing interests: The authors declare that they have no competing interests.

Funding: This study was supported by the Ditmanson Medical Foundation Chia-Yi Christian Hospital Research Program (grant number R105-006).

Authors' contributions: D-CL conceived and designed the study, secured the funding, collected and analyzed the data, interpreted the results, and drafted the manuscript. Y-CT conceived and designed the study, supervised the study, analyzed the data, interpreted the results, and contributed to the writing and revision of manuscript. H-RG conceived and designed the study, supervised the data analysis, interpreted the results, and contributed to the writing and revision of manuscript. All authors read and approved the final manuscript.

Acknowledgements: We would like to thank the Department of Statistics of Ministry of the Interior and the Department of Statistics of the Ministry of the Health and Welfare for providing the registry data and Miss Chao-Hui Weng for her assistance in statistical analysis.

\section{References}

1. Gissler M, Järvelin MR, Louhiala P, Hemminki E. Boys have more health problems in childhood than girls: follow-up of the 1987 Finnish birth cohort. Acta Paediatr. 1999;88:310-14.

2. Zahn-Waxler C, Shirtcliff EA, Marceau K. Disorders of childhood and adolescence: Gender and psychopathology. Annu Rev Clin Psychol. 2008;4:275-303.

3. Yeargin-Allsopp M, Boyle C, Van Naarden Braun K, Trevathan E. The Epidemiology of Developmental Disabilities. In: Accardo PJ, ed. Capute and Accardo's neurodevelopmental disabilities in infancy and childhood. Baltimore, MD: Paul H. Brookes Publishing; 2008, p. 61-104.

4. Thompson T, Caruso M, Ellerbeck K. Sex matters in autism and other developmental disabilities. J Learn Disabil. 2003;7:345-62.

5. Fombonne E. Epidemiology of pervasive developmental disorders. Pediatr Res. 2009;65:591.

6. Leonard H, Wen X. The epidemiology of mental retardation: challenges and opportunities in the new millennium. Ment Retard Dev Disabil Res Rev. 2002;8:117-34.

7. Roeleveld N, Zielhuis GA. The prevalence of mental retardation: a critical review of recent literature. Dev Med Child Neurol. 1997;39:125-32.

8. American Psychiatric Association. Diagnostic and statistical manual of mental disorders, 4th Ed. Washington, DC: American Psychiatric Association; 1994.

9. Cremers CWRJ, Van Rijn PM, Huygen PLM. The sex-ratio in childhood deafness, an analysis of the male predominance. Int J Pediatr Otorhinolaryngol. 1994;30:105-10.

10. Boyle CA, Boulet S, Schieve LA, et al. Trends in the prevalence of developmental disabilities in US children, 1997-2008. Pediatrics. 2011;127:1034-42.

11. China Disabled Persons' Federation. The Second China National Sample Survey on Disability in 2006: The number of disability cases by age, sex , and category. China Disabled Persons' Federation; 2008. Available from: http://www.cdpf.org.cn/sjzx/sjcx/dcsj/200804/t20080407_340123.shtml.

12. China Disabled Persons' Federation. The Second China National Sample Survey on Disability in 2006: The number of survey population by age and sex. China Disabled Persons' Federation; 2008. Available from: http://www.cdpf.org.cn/sjzx/sjcx/dcsj/200804/t20080407_340121.shtml.

13. Zheng X, Chen G, Song X, et al. Twenty-year trends in the prevalence of disability in China. Bull World Health Organ. 2011;89:788-97. 
14. Disabled Welfare Act. The whole text of 26 articles promulgated by President Tai-Tung (1) Yi-Tze No.3028. Taipei, Taiwan: Taiwan Government; 1980.

15. Ministry of Health and Welfare. Statistical yearbook of welfare: 2.3.5 The disabled population by classification and age. Taipei, Taiwan: Ministry of Health and Welfare; 2017. Available from: https://dep.mohw.gov.tw/DOS/cp-2976-13825-113.html.

16. Lai D-C, Tseng Y-C, Hou Y-M, Guo H-R. Gender and geographic differences in the prevalence of autism spectrum disorders in children: Analysis of data from the national disability registry of Taiwan. Res Dev Disabil. 2012;33:909-15.

17. Lai D-C, Tseng Y-C, Hou Y-M, Guo H-R. Gender and geographic differences in the prevalence of intellectual disability in children: Analysis of data from the national disability registry of Taiwan. Res Dev Disabil. 2012;33:2301-7.

18. Lai D-C, Tseng Y-C, Guo H-R. Trends in the prevalence of childhood disability: Analysis of data from the national disability registry of Taiwan, $2000-2011$. Res Dev Disabil. 2013;34:3766-72.

19. Lai D-C, Tseng Y-C, Lin C-Y, Guo H-R. Screening, rubella vaccination, and childhood hearing impairment in Taiwan. Res Dev Disabil. 2014;35:3182-90.

20. Tseng Y-C, Lai D-C, Guo H-R. Gender and geographic differences in the prevalence of reportable childhood speech and language disability in Taiwan. Res Dev Disabil. 2015;40:11-8.

21. Tsai C-F, Guo H-R, Tseng Y-C, Lai D-C. Sex and geographic differences in the prevalence of reported childhood motor disability and their trends in Taiwan. Biomed Res Int. 2018;Article ID 6754230.

22. Lin C-Y, Tseng Y-C, Guo H-R, Lai D-C. Prevalence of childhood hearing impairment of different severities in urban and rural areas: a nationwide populationbased study in Taiwan. BMJ Open. 2018;8:e020955.

23. Department of Health. The Grades of Disabilities, Revision in 2008. Taipei, Taiwan: Department of Health; 2008. Available from: http://www.rootlaw.com.tw/LawArticle.aspx?LawID=A040170031011500-0970701.

24. Department of Health. The Personnel, Methods, and Tools for Certification of Disabilities. Taipei, Taiwan: Department of Health; 2006. Available from: http://www.rootlaw.com.tw/LawContent.aspx?LawID=A040170031011600-0950906.

25. Ministry of Health and Welfare. Statistical yearbook of welfare: 2.3.9 The disabled population by new and old edition. Taipei, Taiwan: Ministry of Health and Welfare; 2017. Available from: https://dep.mohw.gov.tw/DOS/cp-2976-13829-113.html.

26. Department of Health. Regulations on the certification of disabilities. Taipei, Taiwan: Department of Health; 2002. Available from: http://web.it.nctu.edu.tw/ hcsci/service/verify.htm..

27. Ministry of the Interior. Monthly bulletin of interior statistics: 1.11 Population by single year of age and median age. Taipei, Taiwan: Department of Statistics, Ministry of the Interior; 2017.

28. Houtrow AJ, Larson K, Olson LM, Newacheck PW, Halfon N. Changing trends of childhood disability, 2001-2011. Pediatrics. 2014;134:530-8.

29. Bhasin TK, Brocksen S, Avchen RN, Van Naarden Braun K. Prevalence of four developmental disabilities among children aged 8 years: Metropolitan Atlanta Developmental Disabilities Surveillance Program, 1996 and 2000. MMWR Surveill Summ. 2006;55:1-9.

30. Yeargin-Allsopp M, Rice C, Karapurkar T, Doernberg N, Boyle C, Murphy C. Prevalence of autism in a US metropolitan area. JAMA. 2003;289:49-55.

31. Kalkbrenner AE, Schmidt RJ, Penlesky AC. Environmental chemical exposures and autism spectrum disorders: A review of the epidemiological evidence. Curr Probl Pediatr Adolesc Health Care. 2014;44:277-318.

32. Werling DM, Geschwind DH. Sex differences in autism spectrum disorders. Curr Opin Neurol. 2013;26:146-53.

33. National Center for Education Statistics. Children 3 to 21 years old served under Individuals with Disabilities Education Act (IDEA), Part B, by age group and sex, race/ethnicity, and type of disability: 2015-16. National Center for Education Statistics; 2017. Available from: https://nces.ed.gov/programs/digest/d17/tables/dt17_204.50.asp.

34. Sandin S, Lichtenstein P, Kuja-Halkola R, Hultman C, Larsson H, Reichenberg A. The heritability of autism spectrum disorder. JAMA. 2017;318:1182-4.

35. Sandin S, Lichtenstein P, Kuja-Halkola R, Larsson H, Hultman CM, Reichenberg A. The familial risk of autism. JAMA. 2014;311:1770-1777.

36. Bailey A, Le Couteur A, Gottesman I, et al. Autism as a strongly genetic disorder: evidence from a British twin study. Psychol Med. 1995;25:63-77.

37. Hallmayer J, Cleveland S, Torres A, et al. Genetic heritability and shared environmental factors among twin pairs with autism. Arch Gen Psychiatry. 2011;68:1095-102.

38. McLaren J, Bryson SE. Review of recent epidemiological studies of mental retardation: prevalence, associated disorders, and etiology. Am J Ment Retard. 1987;92:243-54.

39. Kaufman L, Ayub M, Vincent JB. The genetic basis of non-syndromic intellectual disability: a review. J Neurodev Disord. $2010 ; 2: 182$.

40. Hou J-W, Wang T-R, Chuang S-M. An epidemiological and aetiological study of children with intellectual disability in Taiwan. $J$ Intellect Disabil Res. 1998;42:137-43.

41. Mehra S, Eavey RD, Keamy Jr DG. The epidemiology of hearing impairment in the United States: newborns, children, and adolescents. Otolaryngol Head Neck Surg. 2009;140:461-72.

42. Jones LA. Census-based prevalence estimates for mental retardation. Ment Retard. 1979;17:199-201.

43. Munro JD. Epidemiology and the extent of mental retardation. Psychiatr Clin North Am. 1986;9:591-24.

44. Lai D-C, Tseng Y-C, Guo H-R. Gender and geographic differences in developmental delays among young children: Analysis of the data from the national registry in Taiwan. Res Dev Disabil. 2011;32:63-9.

45. Lai D-C, Tseng Y-C, Guo H-R. Characteristics of young children with developmental delays and their trends over 14 years in Taiwan: a population-based nationwide study. BMJ Open. 2018;8:e020994.

46. Durkin M. The epidemiology of developmental disabilities in low-income countries. Ment Retard Dev Disabil Res Rev. 2002;8:206-11. 
47. Larson SA, Lakin KC, Anderson L, Kwak Lee N, Lee JH, Anderson D. Prevalence of mental retardation and developmental disabilities: estimates from the 1994/1995 National Health Interview Survey Disability Supplements. Am J Ment Retard. 2001;106:231-52.

\section{Tables}

Table I Prevalence rates (per 1000 children) by sex and male-to-female rate ratios of all disabilities combined in children 3-17 years of age

\begin{tabular}{llllllll} 
Year & \multicolumn{2}{l}{ Number of cases } & \multicolumn{2}{l}{ Population } & \multicolumn{2}{l}{ Prevalence (1/1000) } \\
\cline { 2 - 8 } & Male & Female & Male & Female & Male & Female & Rate ratio [95\% Cl] \\
\hline 2000 & 29535 & 19707 & 2563934 & 2372366 & 11.52 & 8.31 & $1.39[1.36-1.41]^{\star}$ \\
\hline 2001 & 29813 & 19773 & 2508912 & 2318072 & 11.88 & 8.53 & $1.39[1.37-1.42]^{\star}$ \\
\hline 2002 & 31928 & 20926 & 2467763 & 2276454 & 12.94 & 9.19 & $1.41[1.38-1.43]^{\star}$ \\
\hline 2003 & 33151 & 21432 & 2451655 & 2257398 & 13.52 & 9.49 & $1.42[1.40-1.45]^{\star}$ \\
\hline 2004 & 35074 & 22534 & 2429513 & 2234797 & 14.44 & 10.08 & $1.43[1.41-1.46]^{\star}$ \\
\hline 2005 & 36121 & 22904 & 2397970 & 2203863 & 15.06 & 10.39 & $1.45[1.43-1.47]^{\star}$ \\
\hline 2006 & 37131 & 23287 & 2339532 & 2148295 & 15.87 & 10.84 & $1.46[1.44-1.49]^{\star}$ \\
\hline 2007 & 38044 & 23470 & 2292296 & 2102987 & 16.60 & 11.16 & $1.49[1.46-1.51]^{\star}$ \\
\hline 2008 & 38201 & 23516 & 2225403 & 2043227 & 17.17 & 11.51 & $1.49[1.47-1.52]^{\star}$ \\
\hline 2009 & 38337 & 23376 & 2167065 & 1990875 & 17.69 & 11.74 & $1.51[1.48-1.53]^{\star}$ \\
\hline 2010 & 38077 & 23019 & 2107777 & 1936656 & 18.07 & 11.89 & $1.52[1.50-1.54]^{\star}$ \\
\hline 2011 & 37807 & 22565 & 2042826 & 1874817 & 18.51 & 12.04 & $1.54[1.51-1.56]^{\star}$
\end{tabular}

Cl: confidence interval

$* P<0.05$

Table II Prevalence rates (per 1000 children) in each sex by age and male-to-female rate ratios (RRs) by age of all disabilities combined in children 3-17 years of age 


\begin{tabular}{|c|c|c|c|c|c|c|c|c|c|c|c|c|}
\hline \multirow[t]{3}{*}{ Year } & \multicolumn{3}{|c|}{$3-5$ years } & \multicolumn{3}{|c|}{ 6-11 year } & \multicolumn{3}{|c|}{ 12-14 year } & \multicolumn{3}{|c|}{$15-17$ year } \\
\hline & \multicolumn{3}{|c|}{ Prevalence } & \multicolumn{3}{|c|}{ Prevalence } & \multicolumn{3}{|c|}{ Prevalence } & \multicolumn{3}{|c|}{ Prevalence } \\
\hline & Male & Female & $\begin{array}{l}\mathrm{RR}[95 \% \\
\mathrm{Cl}]\end{array}$ & Male & Female & $\begin{array}{l}\mathrm{RR}[95 \% \\
\mathrm{Cl}]\end{array}$ & Male & Female & $\begin{array}{l}\mathrm{RR} \\
{[95 \% \mathrm{Cl}]}\end{array}$ & Male & Female & $\begin{array}{l}\mathrm{RR} \\
{[95 \%} \\
\mathrm{Cl}]\end{array}$ \\
\hline 2000 & 7.09 & 4.92 & $\begin{array}{l}1.44 \\
{[1.37-} \\
1.52]^{\star}\end{array}$ & 11.91 & 8.57 & $\begin{array}{l}1.39 \\
{[1.35-} \\
1.43]^{\star}\end{array}$ & 12.88 & 9.39 & $\begin{array}{l}1.37 \\
{[1.32-} \\
1.43]^{\star}\end{array}$ & 13.64 & 9.92 & $\begin{array}{l}1.38 \\
{[1.33-} \\
1.42]^{\star}\end{array}$ \\
\hline 2001 & 7.46 & 5.36 & $\begin{array}{l}1.39 \\
{[1.32-} \\
1.47]^{\star}\end{array}$ & 12.07 & 8.58 & $\begin{array}{l}1.41 \\
{[1.37-} \\
1.45]^{\star}\end{array}$ & 13.26 & 9.48 & $\begin{array}{l}1.40 \\
{[1.35-} \\
1.45]^{\star}\end{array}$ & 14.27 & 10.39 & $\begin{array}{l}1.37 \\
{[1.33-} \\
1.42]^{\star}\end{array}$ \\
\hline 2002 & 8.88 & 6.20 & $\begin{array}{l}1.43 \\
{[1.36-} \\
1.50]^{\star}\end{array}$ & 13.08 & 9.17 & $\begin{array}{l}1.43 \\
{[1.39-} \\
1.47]^{\star}\end{array}$ & 13.67 & 9.76 & $\begin{array}{l}1.40 \\
{[1.35-} \\
1.45]^{\star}\end{array}$ & 15.66 & 11.40 & $\begin{array}{l}1.37 \\
{[1.33-} \\
1.42]^{\star}\end{array}$ \\
\hline 2003 & 9.45 & 6.57 & $\begin{array}{l}1.44 \\
{[1.37-} \\
1.51]^{\star}\end{array}$ & 13.40 & 9.30 & $\begin{array}{l}1.44 \\
{[1.40-} \\
1.48]^{\star}\end{array}$ & 14.77 & 10.37 & $\begin{array}{l}1.42 \\
{[1.37-} \\
1.48]^{\star}\end{array}$ & 16.19 & 11.62 & $\begin{array}{l}1.39 \\
{[1.35-} \\
1.44]^{\star}\end{array}$ \\
\hline 2004 & 10.63 & 7.05 & $\begin{array}{l}1.51 \\
{[1.44-} \\
1.58]^{\star}\end{array}$ & 14.53 & 9.96 & $\begin{array}{l}1.46 \\
{[1.42-} \\
1.50]^{\star}\end{array}$ & 15.23 & 10.71 & $\begin{array}{l}1.42 \\
{[1.37-} \\
1.47]^{\star}\end{array}$ & 16.83 & 12.35 & $\begin{array}{l}1.36 \\
{[1.32-} \\
1.41]^{\star}\end{array}$ \\
\hline 2005 & 11.30 & 7.28 & $\begin{array}{l}1.55 \\
{[1.48-} \\
1.62]^{\star}\end{array}$ & 15.27 & 10.32 & $\begin{array}{l}1.48 \\
{[1.44-} \\
1.52]^{\star}\end{array}$ & 16.06 & 11.33 & $\begin{array}{l}1.42 \\
{[1.37-} \\
1.47]^{\star}\end{array}$ & 16.79 & 12.16 & $\begin{array}{l}1.38 \\
{[1.34-} \\
1.43]^{\star}\end{array}$ \\
\hline 2006 & 12.26 & 7.86 & $\begin{array}{l}1.60 \\
{[1.49-} \\
1.64]^{\star}\end{array}$ & 16.09 & 10.68 & $\begin{array}{l}1.51 \\
{[1.47-} \\
1.55]^{\star}\end{array}$ & 16.52 & 11.70 & $\begin{array}{l}1.41 \\
{[1.36-} \\
1.46]^{\star}\end{array}$ & 17.54 & 12.55 & $\begin{array}{l}1.40 \\
{[1.35-} \\
1.44]^{\star}\end{array}$ \\
\hline 2007 & 12.25 & 7.86 & $\begin{array}{l}1.56 \\
{[1.49-} \\
1.64]^{\star}\end{array}$ & 17.26 & 11.11 & $\begin{array}{l}1.55 \\
{[1.52-} \\
1.59]^{\star}\end{array}$ & 16.91 & 11.97 & $\begin{array}{l}1.41 \\
{[1.37-} \\
1.46]^{\star}\end{array}$ & 18.18 & 12.80 & $\begin{array}{l}1.42 \\
{[1.38-} \\
1.47]^{\star}\end{array}$ \\
\hline 2008 & 12.40 & 7.75 & $\begin{array}{l}1.60 \\
{[1.52-} \\
1.68]^{\star}\end{array}$ & 18.14 & 11.55 & $\begin{array}{l}1.57 \\
{[1.53-} \\
1.61]^{*}\end{array}$ & 17.16 & 12.04 & $\begin{array}{l}1.43 \\
{[1.38-} \\
1.47]^{*}\end{array}$ & 18.72 & 13.44 & $\begin{array}{l}1.39 \\
{[1.35-} \\
1.44]^{\star}\end{array}$ \\
\hline 2009 & 12.70 & 7.82 & $\begin{array}{l}1.62 \\
{[1.55-} \\
1.71]^{\star}\end{array}$ & 18.74 & 11.93 & $\begin{array}{l}1.57 \\
{[1.53-} \\
1.61]^{\star}\end{array}$ & 17.77 & 12.04 & $\begin{array}{l}1.48 \\
{[1.43-} \\
1.53]^{\star}\end{array}$ & 19.16 & 13.70 & $\begin{array}{l}1.40 \\
{[1.36-} \\
1.44]^{\star}\end{array}$ \\
\hline 2010 & 12.45 & 7.47 & $\begin{array}{l}1.67 \\
{[1.58-} \\
1.76]^{\star}\end{array}$ & 19.13 & 12.02 & $\begin{array}{l}1.59 \\
{[1.55-} \\
1.63]^{\star}\end{array}$ & 18.71 & 12.59 & $\begin{array}{l}1.49 \\
{[1.44-} \\
1.54]^{\star}\end{array}$ & 19.36 & 13.82 & $\begin{array}{l}1.40 \\
{[1.36-} \\
1.45]^{\star}\end{array}$ \\
\hline 2011 & 12.14 & 7.28 & $\begin{array}{l}1.67 \\
{[1.58-} \\
1.76]^{\star}\end{array}$ & 19.68 & 12.27 & $\begin{array}{l}1.60 \\
{[1.56-} \\
1.65]^{\star}\end{array}$ & 19.74 & 12.85 & $\begin{array}{l}1.54 \\
{[1.49-} \\
1.59]^{\star}\end{array}$ & 19.66 & 13.95 & $\begin{array}{l}1.41 \\
{[1.37-} \\
1.45]^{\star}\end{array}$ \\
\hline
\end{tabular}

Cl: confidence interval

$\star P<0.05$

Table III Prevalence rates (per 1000 children) by sex and male-to-female rate ratios (RRs) of nine major disabilities ${ }^{a}$ in children 3-17 years of age 


\begin{tabular}{|c|c|c|c|c|c|c|c|c|c|c|c|c|}
\hline \multirow[t]{3}{*}{ Year } & \multicolumn{3}{|c|}{ Autism spectrum disorder } & \multicolumn{3}{|c|}{$\begin{array}{l}\text { Speech and language } \\
\text { disability }\end{array}$} & \multicolumn{3}{|c|}{ Multiple disabilities } & \multicolumn{3}{|c|}{ Intellectual disability } \\
\hline & \multicolumn{3}{|c|}{ Prevalence } & \multicolumn{3}{|c|}{ Prevalence } & \multicolumn{3}{|c|}{ Prevalence } & \multicolumn{3}{|c|}{ Prevalence } \\
\hline & Male & Female & $\begin{array}{l}\mathrm{RR}[95 \% \\
\mathrm{Cl}]\end{array}$ & Male & Female & $\begin{array}{l}\mathrm{RR}[95 \% \\
\mathrm{Cl}]\end{array}$ & Male & Female & $\begin{array}{l}\mathrm{RR}[95 \% \\
\mathrm{Cl}]\end{array}$ & Male & Female & $\begin{array}{l}\text { RR } \\
{[95 \%} \\
\mathrm{Cl}]\end{array}$ \\
\hline 2000 & 0.62 & 0.11 & $\begin{array}{l}5.79 \\
{[5.07-} \\
6.61]^{\star}\end{array}$ & 0.22 & 0.16 & $\begin{array}{l}1.36 \\
{[1.19-} \\
1.55]^{\star}\end{array}$ & 2.15 & 1.54 & $\begin{array}{l}1.40 \\
{[1.34-} \\
1.46]^{\star}\end{array}$ & 4.17 & 2.98 & $\begin{array}{l}1.40 \\
{[1.36-} \\
1.44]^{\star}\end{array}$ \\
\hline 2001 & 0.78 & 0.14 & $\begin{array}{l}5.66 \\
{[5.03-} \\
6.37]^{\star}\end{array}$ & 0.25 & 0.18 & $\begin{array}{l}1.36 \\
{[1.20-} \\
1.53]^{\star}\end{array}$ & 2.19 & 1.56 & $\begin{array}{l}1.41 \\
{[1.35-} \\
1.47]^{\star}\end{array}$ & 4.24 & 3.05 & $\begin{array}{l}1.39 \\
{[1.35-} \\
1.43]^{\star}\end{array}$ \\
\hline 2002 & 0.97 & 0.17 & $\begin{array}{l}5.76 \\
{[5.17-} \\
6.41]^{\star}\end{array}$ & 0.28 & 0.20 & $\begin{array}{l}1.36 \\
{[1.21-} \\
1.53]^{\star}\end{array}$ & 2.36 & 1.67 & $\begin{array}{l}1.41 \\
{[1.35-} \\
1.47]^{*}\end{array}$ & 4.54 & 3.27 & $\begin{array}{l}1.39 \\
{[1.35-} \\
1.43]^{\star}\end{array}$ \\
\hline 2003 & 1.18 & 0.19 & $\begin{array}{l}6.07 \\
{[5.49-} \\
6.71]^{\star}\end{array}$ & 0.31 & 0.22 & $\begin{array}{l}1.42 \\
{[1.27-} \\
1.60]^{\star}\end{array}$ & 2.41 & 1.72 & $\begin{array}{l}1.41 \\
{[1.35-} \\
1.47]^{\star}\end{array}$ & 4.71 & 3.41 & $\begin{array}{l}1.38 \\
{[1.34-} \\
1.42]^{\star}\end{array}$ \\
\hline 2004 & 1.42 & 0.25 & $\begin{array}{l}5.75 \\
{[5.26-} \\
6.29]^{*}\end{array}$ & 0.36 & 0.24 & $\begin{array}{l}1.50 \\
{[1.34-} \\
1.66]^{\star}\end{array}$ & 2.55 & 1.80 & $\begin{array}{l}1.42 \\
{[1.36-} \\
1.47]^{\star}\end{array}$ & 5.06 & 3.69 & $\begin{array}{l}1.37 \\
{[1.33-} \\
1.41]^{\star}\end{array}$ \\
\hline 2005 & 1.68 & 0.30 & $\begin{array}{l}5.64 \\
{[5.20-} \\
6.13]^{\star}\end{array}$ & 0.38 & 0.25 & $\begin{array}{l}1.52 \\
{[1.37-} \\
1.69]^{\star}\end{array}$ & 2.65 & 1.86 & $\begin{array}{l}1.43 \\
{[1.37-} \\
1.48]^{\star}\end{array}$ & 5.28 & 3.85 & $\begin{array}{l}1.37 \\
{[1.34-} \\
1.41]^{\star}\end{array}$ \\
\hline 2006 & 1.97 & 0.34 & $\begin{array}{l}5.85 \\
{[5.41-} \\
6.33]^{\star}\end{array}$ & 0.41 & 0.27 & $\begin{array}{l}1.53 \\
{[1.38-} \\
1.70]^{\star}\end{array}$ & 2.73 & 1.91 & $\begin{array}{l}1.43 \\
{[1.38-} \\
1.49]^{\star}\end{array}$ & 5.62 & 4.10 & $\begin{array}{l}1.37 \\
{[1.33-} \\
1.41]^{\star}\end{array}$ \\
\hline 2007 & 2.31 & 0.39 & $\begin{array}{l}5.97 \\
{[5.55-} \\
6.43]^{\star}\end{array}$ & 0.44 & 0.27 & $\begin{array}{l}1.63 \\
{[1.47-} \\
1.81]^{\star}\end{array}$ & 2.81 & 1.95 & $\begin{array}{l}1.44 \\
{[1.39-} \\
1.50]^{\star}\end{array}$ & 5.94 & 4.33 & $\begin{array}{l}1.37 \\
{[1.34-} \\
1.41]^{\star}\end{array}$ \\
\hline 2008 & 2.64 & 0.44 & $\begin{array}{l}6.00 \\
{[5.60-} \\
6.44]^{\star}\end{array}$ & 0.47 & 0.28 & $\begin{array}{l}1.71 \\
{[1.54-} \\
1.90]^{\star}\end{array}$ & 2.88 & 1.98 & $\begin{array}{l}1.45 \\
{[1.40-} \\
1.51]^{*}\end{array}$ & 6.22 & 4.59 & $\begin{array}{l}1.35 \\
{[1.32-} \\
1.39]^{\star}\end{array}$ \\
\hline 2009 & 3.00 & 0.49 & $\begin{array}{l}6.06 \\
{[5.66-} \\
6.48]^{\star}\end{array}$ & 0.47 & 0.27 & $\begin{array}{l}1.76 \\
{[1.59-} \\
1.96]^{\star}\end{array}$ & 2.88 & 2.02 & $\begin{array}{l}1.43 \\
{[1.37-} \\
1.48]^{\star}\end{array}$ & 6.45 & 4.81 & $\begin{array}{l}1.34 \\
{[1.31-} \\
1.38]^{\star}\end{array}$ \\
\hline 2010 & 3.33 & 0.55 & $\begin{array}{l}6.06 \\
{[5.69-} \\
6.47]^{\star}\end{array}$ & 0.52 & 0.28 & $\begin{array}{l}1.83 \\
{[1.65-} \\
2.02]^{\star}\end{array}$ & 2.93 & 2.04 & $\begin{array}{l}1.43 \\
{[1.38-} \\
1.49]^{*}\end{array}$ & 6.57 & 4.93 & $\begin{array}{l}1.33 \\
{[1.30-} \\
1.37]^{\star}\end{array}$ \\
\hline 2011 & 3.68 & 0.62 & $\begin{array}{l}5.97 \\
{[5.61-} \\
6.35]^{\star}\end{array}$ & 0.54 & 0.29 & $\begin{array}{l}1.85 \\
{[1.67-} \\
2.05]^{\star}\end{array}$ & 2.98 & 2.06 & $\begin{array}{l}1.45 \\
{[1.39-} \\
1.51]^{\star}\end{array}$ & 6.68 & 5.08 & $\begin{array}{l}1.32 \\
{[1.28-} \\
1.35]^{\star}\end{array}$ \\
\hline
\end{tabular}




\begin{tabular}{|c|c|c|c|c|c|c|c|c|c|c|c|c|}
\hline \multirow[t]{3}{*}{ Year } & \multicolumn{3}{|c|}{ Motor disability } & \multicolumn{3}{|c|}{ Visual impairment } & \multicolumn{3}{|c|}{ Other disabilities } & \multicolumn{3}{|c|}{$\begin{array}{l}\text { Loss of function of major } \\
\text { organs }\end{array}$} \\
\hline & \multicolumn{3}{|c|}{ Prevalence } & \multicolumn{3}{|c|}{ Prevalence } & \multicolumn{3}{|c|}{ Prevalence } & \multicolumn{3}{|c|}{ Prevalence } \\
\hline & Male & Female & $\begin{array}{l}\mathrm{RR}[95 \% \\
\mathrm{Cl}]\end{array}$ & Male & Female & $\begin{array}{l}\mathrm{RR}[95 \% \\
\mathrm{Cl}]\end{array}$ & Male & Female & $\begin{array}{l}\mathrm{RR}[95 \% \\
\mathrm{Cl}]\end{array}$ & Male & Female & $\begin{array}{l}\text { RR } \\
{[95 \%} \\
\mathrm{Cl}]\end{array}$ \\
\hline 2000 & 1.86 & 1.33 & $\begin{array}{l}1.40 \\
{[1.34-} \\
1.46]^{\star}\end{array}$ & 0.34 & 0.28 & $\begin{array}{l}1.23 \\
{[1.11-} \\
1.36]^{\star}\end{array}$ & 0.35 & 0.29 & $\begin{array}{l}1.22 \\
{[1.10-} \\
1.34]^{\star}\end{array}$ & 0.79 & 0.65 & $\begin{array}{l}1.13 \\
{[1.06-} \\
1.20]^{\star}\end{array}$ \\
\hline 2001 & 1.87 & 1.38 & $\begin{array}{l}1.36 \\
{[1.30-} \\
1.42]^{\star}\end{array}$ & 0.35 & 0.28 & $\begin{array}{l}1.25 \\
{[1.13-} \\
1.38]^{*}\end{array}$ & 0.40 & 0.32 & $\begin{array}{l}1.26 \\
{[1.14-} \\
1.38]^{\star}\end{array}$ & 0.79 & 0.64 & $\begin{array}{l}1.14 \\
{[1.07-} \\
1.22]^{\star}\end{array}$ \\
\hline 2002 & 2.00 & 1.45 & $\begin{array}{l}1.38 \\
{[1.32-} \\
1.44]^{\star}\end{array}$ & 0.38 & 0.30 & $\begin{array}{l}1.27 \\
{[1.15-} \\
1.40]^{\star}\end{array}$ & 0.46 & 0.36 & $\begin{array}{l}1.28 \\
{[1.17-} \\
1.40]^{\star}\end{array}$ & 0.87 & 0.71 & $\begin{array}{l}1.13 \\
{[1.06-} \\
1.20]^{\star}\end{array}$ \\
\hline 2003 & 2.00 & 1.47 & $\begin{array}{l}1.36 \\
{[1.31-} \\
1.43]^{\star}\end{array}$ & 0.38 & 0.30 & $\begin{array}{l}1.30 \\
{[1.18-} \\
1.43]^{\star}\end{array}$ & 0.48 & 0.39 & $\begin{array}{l}1.23 \\
{[1.12-} \\
1.34]^{\star}\end{array}$ & 0.90 & 0.73 & $\begin{array}{l}1.14 \\
{[1.07-} \\
1.21]^{\star}\end{array}$ \\
\hline 2004 & 2.01 & 1.48 & $\begin{array}{l}1.36 \\
{[1.30-} \\
1.42]^{\star}\end{array}$ & 0.39 & 0.30 & $\begin{array}{l}1.28 \\
{[1.16-} \\
1.41]^{\star}\end{array}$ & 0.51 & 0.43 & $\begin{array}{l}1.19 \\
{[1.10-} \\
1.30]^{\star}\end{array}$ & 0.93 & 0.76 & $\begin{array}{l}1.13 \\
{[1.06-} \\
1.20]^{\star}\end{array}$ \\
\hline 2005 & 2.01 & 1.45 & $\begin{array}{l}1.39 \\
{[1.33-} \\
1.45]^{\star}\end{array}$ & 0.40 & 0.31 & $\begin{array}{l}1.29 \\
{[1.17-} \\
1.43]^{\star}\end{array}$ & 0.53 & 0.44 & $\begin{array}{l}1.19 \\
{[1.09-} \\
1.29]^{\star}\end{array}$ & 0.91 & 0.77 & $\begin{array}{l}1.09 \\
{[1.03-} \\
1.16]^{\star}\end{array}$ \\
\hline 2006 & 2.00 & 1.46 & $\begin{array}{l}1.38 \\
{[1.31-} \\
1.44]^{\star}\end{array}$ & 0.41 & 0.32 & $\begin{array}{l}1.30 \\
{[1.18-} \\
1.43]^{\star}\end{array}$ & 0.53 & 0.46 & $\begin{array}{l}1.15 \\
{[1.06-} \\
1.25]^{*}\end{array}$ & 0.92 & 0.77 & $\begin{array}{l}1.09 \\
{[1.03-} \\
1.16]^{\star}\end{array}$ \\
\hline 2007 & 1.93 & 1.45 & $\begin{array}{l}1.33 \\
{[1.27-} \\
1.40]^{\star}\end{array}$ & 0.41 & 0.32 & $\begin{array}{l}1.27 \\
{[1.15-} \\
1.40]^{\star}\end{array}$ & 0.54 & 0.47 & $\begin{array}{l}1.14 \\
{[1.05-} \\
1.24]^{\star}\end{array}$ & 0.91 & 0.75 & $\begin{array}{l}1.12 \\
{[1.05-} \\
1.19]^{\star}\end{array}$ \\
\hline 2008 & 1.81 & 1.41 & $\begin{array}{l}1.29 \\
{[1.23-} \\
1.35]^{*}\end{array}$ & 0.40 & 0.32 & $\begin{array}{l}1.24 \\
{[1.12-} \\
1.37]^{\star}\end{array}$ & 0.53 & 0.49 & $\begin{array}{l}1.09 \\
{[1.00-} \\
1.18]\end{array}$ & 0.89 & 0.74 & $\begin{array}{l}1.11 \\
{[1.04-} \\
1.18]^{\star}\end{array}$ \\
\hline 2009 & 1.73 & 1.35 & $\begin{array}{l}1.28 \\
{[1.22-} \\
1.34]^{\star}\end{array}$ & 0.41 & 0.32 & $\begin{array}{l}1.27 \\
{[1.14-} \\
1.40]^{*}\end{array}$ & 0.53 & 0.49 & $\begin{array}{l}1.08 \\
{[0.99-} \\
1.18]\end{array}$ & 0.88 & 0.71 & $\begin{array}{l}1.14 \\
{[1.07-} \\
1.22]^{\star}\end{array}$ \\
\hline 2010 & 1.65 & 1.31 & $\begin{array}{l}1.26 \\
{[1.19-} \\
1.32]^{\star}\end{array}$ & 0.40 & 0.31 & $\begin{array}{l}1.29 \\
{[1.16-} \\
1.43]^{*}\end{array}$ & 0.52 & 0.49 & $\begin{array}{l}1.07 \\
{[0.98-} \\
1.17]\end{array}$ & 0.83 & 0.68 & $\begin{array}{l}1.12 \\
{[1.05-} \\
1.20]^{\star}\end{array}$ \\
\hline 2011 & 1.60 & 1.27 & $\begin{array}{l}1.26 \\
{[1.19-} \\
1.33]^{\star}\end{array}$ & 0.39 & 0.30 & $\begin{array}{l}1.32 \\
{[1.19-} \\
1.47]^{\star}\end{array}$ & 0.54 & 0.50 & $\begin{array}{l}1.08 \\
{[0.99-} \\
1.17]\end{array}$ & 0.78 & 0.64 & $\begin{array}{l}1.11 \\
{[1.03-} \\
1.20]^{\star}\end{array}$ \\
\hline
\end{tabular}




\begin{tabular}{|c|c|c|c|}
\hline \multirow{3}{*}{ Year } & \multicolumn{3}{|c|}{ Hearing impairment } \\
\hline & \multicolumn{3}{|c|}{ Prevalence } \\
\hline & Male & Female & $\mathrm{RR}[95 \% \mathrm{Cl}]$ \\
\hline 2000 & 0.80 & 0.73 & $1.10[1.03-1.17]^{\star}$ \\
\hline 2001 & 0.80 & 0.75 & $1.07[1.01-1.15]^{\star}$ \\
\hline 2002 & 0.84 & 0.78 & $1.08[1.01-1.15]^{\star}$ \\
\hline 2003 & 0.86 & 0.77 & $1.11[1.05-1.19]^{*}$ \\
\hline 2004 & 0.88 & 0.79 & $1.12[1.05-1.19]^{\star}$ \\
\hline 2005 & 0.87 & 0.80 & $1.08[1.02-1.15]^{\star}$ \\
\hline 2006 & 0.88 & 0.82 & $1.07[1.00-1.14]^{\star}$ \\
\hline 2007 & 0.87 & 0.81 & $1.07[1.01-1.15]^{\star}$ \\
\hline 2008 & 0.85 & 0.80 & $1.07[1.00-1.15]^{\star}$ \\
\hline 2009 & 0.86 & 0.79 & $1.09[1.02-1.16]^{\star}$ \\
\hline 2010 & 0.85 & 0.79 & 1.07 [1.00-1.15] \\
\hline 2011 & 0.84 & 0.80 & $1.05[0.98-1.13]$ \\
\hline
\end{tabular}

a autism spectrum disorders, hearing impairment, intellectual disability, loss of function of major organs, motor disability, multiple disabilities, other disabilities listed by the government, speech and language disability, and visual impairment; data are presented in the descending order of the mean male-to-female RR

Cl: confidence interval, $* P<0.05$

Table IV Prevalence rates (per 1000 children) by sex and age and male-to-female rate ratios (RRs) by age of nine major disabilities ${ }^{\mathrm{a}}$ in children $3-17$ years of age in 2011 


\begin{tabular}{|c|c|c|c|c|c|c|c|c|c|c|c|c|}
\hline \multirow{4}{*}{$\begin{array}{l}\text { Type of } \\
\text { disability }\end{array}$} & \multirow{2}{*}{\multicolumn{3}{|c|}{$\begin{array}{l}3-5 \text { years } \\
\text { Prevalence }\end{array}$}} & \multirow{2}{*}{\multicolumn{3}{|c|}{$\begin{array}{l}\text { 6-11 year } \\
\text { Prevalence }\end{array}$}} & \multicolumn{3}{|c|}{$12-14$ year } & \multicolumn{3}{|c|}{ 15-17 year } \\
\hline & & & & & & & & & & Preval & nce & \\
\hline & \multirow[t]{2}{*}{ Male } & \multirow[t]{2}{*}{ Female } & \multirow{2}{*}{$\begin{array}{l}\text { RR } \\
{[95 \%} \\
\mathrm{Cl}]\end{array}$} & \multirow[t]{2}{*}{ Male } & \multirow[t]{2}{*}{ Female } & \multirow{2}{*}{$\begin{array}{l}\text { RR } \\
{[95 \%} \\
\text { Cl] }\end{array}$} & \multirow[t]{2}{*}{ Male } & \multirow[t]{2}{*}{ Female } & \multirow{2}{*}{$\begin{array}{l}\text { RR } \\
{[95 \%} \\
\mathrm{Cl}]\end{array}$} & \multirow[t]{2}{*}{ Male } & \multirow[t]{2}{*}{ Female } & \multirow{2}{*}{$\begin{array}{l}\text { RR } \\
{[95 \%} \\
\mathrm{Cl}]\end{array}$} \\
\hline & & & & & & & & & & & & \\
\hline $\begin{array}{l}\text { Autism } \\
\text { spectrum } \\
\text { disorder }\end{array}$ & 2.59 & 0.48 & $\begin{array}{l}5.42 \\
{[4.53-} \\
6.48]^{*}\end{array}$ & 4.64 & 0.82 & $\begin{array}{l}5.68 \\
{[5.20-} \\
6.20]^{\star}\end{array}$ & 3.79 & 0.59 & $\begin{array}{l}6.47 \\
{[5.66-} \\
7.40]^{\star}\end{array}$ & 2.81 & 0.43 & $\begin{array}{l}6.57 \\
{[5.67-} \\
7.62]^{\star}\end{array}$ \\
\hline $\begin{array}{l}\text { Hearing } \\
\text { impairment }\end{array}$ & 0.69 & 0.62 & $\begin{array}{l}1.10 \\
{[0.91-} \\
1.34]\end{array}$ & 0.82 & 0.79 & $\begin{array}{l}1.05 \\
{[0.93-} \\
1.17]\end{array}$ & 0.86 & 0.81 & $\begin{array}{l}1.07 \\
{[0.92-} \\
1.23]\end{array}$ & 0.95 & 0.92 & $\begin{array}{l}1.04 \\
{[0.91-} \\
1.18]\end{array}$ \\
\hline $\begin{array}{l}\text { Intellectual } \\
\text { disability }\end{array}$ & 2.82 & 1.66 & $\begin{array}{l}1.70 \\
{[1.53-} \\
1.90]^{\star}\end{array}$ & 6.83 & 5.00 & $\begin{array}{l}1.37 \\
{[1.31-} \\
1.42]^{\star}\end{array}$ & 7.68 & 5.88 & $\begin{array}{l}1.31 \\
{[1.24-} \\
1.38]^{\star}\end{array}$ & 8.00 & 6.61 & $\begin{array}{l}1.21 \\
{[1.15-} \\
1.27]^{*}\end{array}$ \\
\hline $\begin{array}{l}\text { Loss of } \\
\text { function of } \\
\text { major } \\
\text { organs }\end{array}$ & 0.52 & 0.53 & $\begin{array}{l}0.97 \\
{[0.78-} \\
1.21]\end{array}$ & 0.80 & 0.71 & $\begin{array}{l}1.12 \\
{[0.99-} \\
1.26]\end{array}$ & 0.80 & 0.70 & $\begin{array}{l}1.15 \\
{[0.98-} \\
1.34]\end{array}$ & 0.89 & 0.78 & $\begin{array}{l}1.14 \\
{[0.99-} \\
1.31]\end{array}$ \\
\hline $\begin{array}{l}\text { Motor } \\
\text { disability }\end{array}$ & 1.28 & 1.00 & $\begin{array}{l}1.28 \\
{[1.10-} \\
1.49]^{*}\end{array}$ & 1.44 & 1.17 & $\begin{array}{l}1.23 \\
{[1.13-} \\
1.35]^{\star}\end{array}$ & 1.78 & 1.41 & $\begin{array}{l}1.27 \\
{[1.14-} \\
1.41]^{\star}\end{array}$ & 1.89 & 1.49 & $\begin{array}{l}1.27 \\
{[1.15-} \\
1.40]^{*}\end{array}$ \\
\hline $\begin{array}{l}\text { Multiple } \\
\text { disabilities }\end{array}$ & 2.15 & 1.59 & $\begin{array}{l}1.35 \\
{[1.20-} \\
1.52]^{\star}\end{array}$ & 3.06 & 2.14 & $\begin{array}{l}1.43 \\
{[1.34-} \\
1.53]^{\star}\end{array}$ & 3.19 & 2.13 & $\begin{array}{l}1.50 \\
{[1.38-} \\
1.63]^{\star}\end{array}$ & 3.21 & 2.16 & $\begin{array}{l}1.49 \\
{[1.37-} \\
1.61]^{*}\end{array}$ \\
\hline \multirow{2}{*}{$\begin{array}{l}\text { Other } \\
\text { disabilities }\end{array}$} & \multirow[t]{2}{*}{0.56} & \multirow[t]{2}{*}{0.45} & \multirow{2}{*}{$\begin{array}{l}1.26 \\
{[1.00-} \\
1.57]\end{array}$} & \multirow[t]{2}{*}{0.56} & \multirow[t]{2}{*}{0.63} & \multirow{2}{*}{$\begin{array}{l}0.90 \\
{[0.79-} \\
1.03]\end{array}$} & \multirow[t]{2}{*}{0.53} & \multirow[t]{2}{*}{0.44} & 1.19 & \multirow[t]{2}{*}{0.49} & \multirow[t]{2}{*}{0.39} & \multirow{2}{*}{$\begin{array}{l}1.25 \\
{[1.04-} \\
1.52]^{*}\end{array}$} \\
\hline & & & & & & & & & $\begin{array}{l}{[0.98-} \\
1.45]\end{array}$ & & & \\
\hline $\begin{array}{l}\text { Speech and } \\
\text { language } \\
\text { disability }\end{array}$ & 1.06 & 0.50 & $\begin{array}{l}2.13 \\
{[1.75-} \\
2.58]^{\star}\end{array}$ & 0.73 & 0.38 & $\begin{array}{l}1.91 \\
{[1.65-} \\
2.21]^{\star}\end{array}$ & 0.24 & 0.15 & $\begin{array}{l}1.59 \\
{[1.16-} \\
2.17]^{\star}\end{array}$ & 0.19 & 0.15 & $\begin{array}{l}1.25 \\
{[0.91-} \\
1.70]\end{array}$ \\
\hline $\begin{array}{l}\text { Visual } \\
\text { impairment }\end{array}$ & 0.15 & 0.12 & $\begin{array}{l}1.24 \\
{[0.81-} \\
1.91]\end{array}$ & 0.35 & 0.27 & $\begin{array}{l}1.28 \\
{[1.06-} \\
1.54]^{\star}\end{array}$ & 0.43 & 0.33 & $\begin{array}{l}1.29 \\
{[1.04-} \\
1.61]^{\star}\end{array}$ & 0.57 & 0.41 & $\begin{array}{l}1.41 \\
{[1.17-} \\
1.69]^{\star}\end{array}$ \\
\hline $\begin{array}{l}\text { All } \\
\text { disabilities } \\
\text { combined }\end{array}$ & 12.14 & 7.28 & $\begin{array}{l}1.67 \\
{[1.58-} \\
1.76]^{*}\end{array}$ & 19.68 & 12.27 & $\begin{array}{l}1.60 \\
{[1.56-} \\
1.65]^{\star}\end{array}$ & 19.74 & 12.85 & $\begin{array}{l}1.54 \\
{[1.49-} \\
1.59]^{\star}\end{array}$ & 19.66 & 13.95 & $\begin{array}{l}1.41 \\
{[1.37-} \\
1.45]^{*}\end{array}$ \\
\hline
\end{tabular}

Cl: confidence interval, ${ }^{\star} P<0.05$

\section{Supplementary Files}

This is a list of supplementary files associated with this preprint. Click to download.

- supptable1.docx 